\title{
"Petuah" Kiai Charismatic To The Construction Of Cement Plant in Rembang
}

\author{
Ahmad Hariyadi ${ }^{1}$, Joko Setiyono ${ }^{2}$ \\ \{ahmadhariyadi86@gmail.com¹,jokosetiyono@gmail.com²\} \\ ${ }^{1,2}$ IKIP PGRI Bojonegoro, Indonesia
}

\begin{abstract}
This study aimed to find "Petuah" kiai charismatic in Rembang. In the case, the construction of a cement factory does not in a well situation. This study used a qualitative approach and a phenomenology. The results of this research are the development in Islamic studies which are equated with barokah. Barokah means the basic development which should create benefits for the entire Rembang community and does not include a problem. This study concludes that "Petuah" kiai charismatic in Rembang has some influences on the expansion of the development, especially the construction of the cement plant.
\end{abstract}

Keywords: petuah, charismatic's kiai, usefulness, cement plant

\section{Introduction}

In 2011, there was a conflict in the cement factory in Rembang until now. It impacted the thought dilemma which is in the inner unrest among religious leaders. There is a paradox presumption in cement factory which means many problems exist inside such as environment, social and culture (Puryanto, 2018a, 2019b, 2019c). As a result, the society split into two camps, where there are in "benefit" or "importance". This thought is contradictive and has ideology development until now.

The different point of view as the principle factor from society is because there are two different sides which are stated by Kiai as the central wisdom for the common good. According to Haryadi (2018) Kiai becomes the leader of the ummah and becomes the legitimacy of his citizens which implies the basis of a religious foothold in doing his actions so that the people only listen to and obey him (sami'na wa atho'na) when the Kiai says something. It means that he is as the role model and the example of society. He also becomes an important role as the person who can solve problems in their environment. The differences in point of view are common in society. It mentioned clearly if a perception difference from Kiai in Rembang to the cement factory has the acceptance and rejection. Those are formed in the statement and attitude which are shown brightly and secretly.

The viewpoint differences are common among religious leaders. However, it is not for the low society which still has little knowledge in general or religion field. The religious leader's statement about the cement factory's point of view cannot clearly be understood by the general society and its possibility has the wrong interpretation from the statement's rendering which is claimed. Therefore, the right and clear transformation are needed to the point of view differences of Kiai to the general society through the advice and blessing from the Kiai charismatic. 
The ideality understanding of "blessing", "benefit" or "importance" are having the usefulness and the goodness to all people from all life concept including economy, social culture, and environment. It is included in some life concepts especially in the cement factory development which still contains an epistemology debate about the real benefit to the practice. That, the practice is leaving some problems and those still cannot be explained yet in the completion, particularly on the Kiai charismatic.

The blessing meaning between Kiai charismatic and society is known by the people as the very differences point of view. It implemented from how is the socialization to the knowledge internalization and culture. Those are obtained from the correct mechanism process. In the other premise, society only receives instant natural knowledge. From this case, it makes the problems' context of inductive-deductive and those deductive-inductive and make the polemic in the cement factory and it has continuity until this day.

The society critical thought which is flourishing about the blessing meaning still has the partial practice. On the other word, it does not be understood yet by the whole meaning and intimate. This philosophy creates the blessing frame and only seen at the empirical externally. Whereas, for the Kiai charismatic, the blessing is interpreted as the non-external which has the highest cosmos metaphysic from the mysticism intuition or the vision from God.

This research explains the blessing paradigm from the kiai charismatic in Rembang subdistrict. It is also deeply understanding of the blessing meaning completely.

\section{Research Method}

This research used qualitative phenomenology's approach and mix hermeneutic. This qualitative approach is used to understand the phenomena in the cement factory and society. They are as the Kiai and religious leaders who have a different perspective in fathoming. The blessing symbol meaning is as the ontology from the whole development in social culture and environment. It is like prosperity, fortune, and benefit for all people from the whole contents. The observation is done to the social phenomenon, religious leaders and the cement factory. There were interview and documentation to make the clear data. The hermeneutic study is about the highest cosmos blessing which is done by using academic and religious studies. The data analysis used a reductive technique, verification, and conclusion.

\section{Result and Discussion}

The ideality of "kiai charismatic" which figured out by Sukamto (1999) is as the problem solving for the society in all cases. It used the openness, egalitarian, and inclusivity which has the contradictive function to the cement development in Rembang. The perspective claiming in the society critical subject generates a thought reconstruction in society. It makes a critical thought to the knowledge from a science specification in a believing if it cannot give the benefit idealism yet.

The differences of point of view from Kiai charismatic in Rembang is as the knowledge objectivity which has a contradictive value and argument equality from Sukarno (2013a, 2016b) from the two different society perceptions to the cement development. There are following economy objectivity, environment conservation and also socio-culture (Puryanto, 2019). Other, the knowledge is partial and has non-complex diaspora effect which has the continuity effect.

The development of knowledge for Kiai charismatic is from an economic perspective. It is rendered to the economy beneficiary to society. Meaning that they can fulfill their economic 
need such as the chance of many jobs, for example being the cement factory's office or the entrepreneur for the impacted factory cement. The economy beneficiary is affiliated with the primary and secondary needs as the society basic need.

Macintyre (2013) stated there is the benefit of development from the economy factor on his research. It found if the mining has already given the significant economy chance to the local society. However, this economic chance mainly in the benefit of distribution including the society partition process and the disadvantage in the long term.

Sethi, et al (2011) also found in her research in the gold mining done by FreeportMcmoran Copper \&Gold. It prioritized in the human rights' case and emphasized in the local society maintenance, where the factory is built (treatment of indigenous people on whose traditional land its mine was located); the economy development and the jobs available and the enhancement of education, healthy and housing facilities (Maria \& Devuyst : 2011).

While the Kiai charismatic viewed the cement factory development from the socio-culture and environment perspective. He also criticizes the partial economy perspective. The blessing delivery is not only on the economy's side but also in the whole such as the blessing economy, socio-culture, and environment. Meaning that, the blessing in saving the economy enhancement with socio-culture and environment preservation.

Holdena and Jacobson (2008), Bury, Kolf, 2002, and Ganibay et al (2011) explained if the society's rejection to the mining is because of the environmental pollution, economic gap, officials' conflict, ecology's conflict, oligopoly creation, and imperialism. Or else, the mining development is not on the ideal development's concept yet and having the universal completing blessing value.

\section{Cosmos Philosophies of Blessing (Berkah)}

It expects the blessing from an effort or action by Allah SWT and also becomes a phenomenon in the real situation on life to something or someone who has a privilege on Him. In the perspective and implementation of the Holy Qur'an and Hadith on the education based on the blessing meaning of "ziyadatul khair" or "the goodness enhancement". The religious leaders' have explained as the abundant thing including the blessing of materials and spiritualism like safety, healthy, property, children and age. The blessing (barakah) is the goodness from God where it can be imperishable and increase the closeness to Him because Allah SWT is the almighty giver. The blessing in Holy Qur'an attends with some meanings such as eternity, goodness and adding goodness. The Holy Qur'an also as the blessing to the human with all saying, it can be seen on the verses quotation below:

"[This is] a blessed Book which We have revealed to you, [O Muhammad], that they might reflect upon its verses and that those of understanding would be reminded". (QS. Shaad:29).

The blessing has the meaning as the goodness, safety, and prosperity which are attached to the following verse:

"And if only the people of the cities had believed and feared Allah, We would have opened upon them blessings from the heaven and the earth; but they denied [the messengers], so We seized them for what they were earning". (QS. Al-A'raf:96).

In "Syarah Shahih Muslim" creates by "Imam Nawawi". It mentioned that the blessing has two meanings like 1) grow, develop or increase; and 2) the goodness continuity. He also explained about the eternal and many blessings like the following: 
"And He has made me blessed wherever I may be, and He has enjoined on me the Prayer (As-Salat) and the almsgiving (Az-Zakat) so long I live”. (QS. Maryam: 31)

The blessing is intended on those verses as the decision of Prophet Isa and the religion taught. Moreover, he always gives the benefit to the people he met in everywhere like healing the sick people and taught them in the goodness and "Amar ma'ruf nahi munkar". Allah SWT makes the blessing as the object through the thing till the tree and time. The blessing concept is as the effort to get the abundant goodness or advantage through a "mediator" such as someone, something or the thing, place and time. It also the action inside contains the abundant goodness position, especially in His side.

\section{Conclusion}

The advice (petuah) of Kiai charismatic about universal blessing in the cement factory's development in Rembang becomes the reference to the life policy. It is as the guide of general people and has the function in the principle uniting or if they have a different point of view, they have to come together and focus on the development continuity.

\section{References}

Al-Qurthubi, Abu Abdillah Muhammad Ibnu Ahmad Farakh Al-anshari, Al-Jami’ lil Akhla Min Al-Qur'an (Ar-Riyadl: Al-Mamlakah Al-Arabiyah: Daaru Alami Al-kutub, 2003 $\mathrm{M}$

Bainton and Macintyre, 2013. My Land My Work : Business Development and Large Scale Mining In Papua New Guniea. in Fiona Mccormack, Kate Barclay (ed.) Engaging with Capitalism: Cases from Oceania (Research in Economic Anthropology, Volume 33) Emerald Group Publishing Limited, pp.139 - 165

Bury, Kolf, 2002. Livelihoods, Mining and Peasant Protests in The Peruvian Andes. Department of Geography and Human Environmental Sciences San Fransisco State University. Journal of Latin American Geography, Vol 1 No 1 pp 3-16

Devuyst, dan Maria FJ, 2011. CSR and Development: a Mining in Africa. Journal of Management Development, Vol 30 ISS 10 pp 955-967.

Ganibay,at all, 2011. Unequal Partners, Unequal Exchange: Gold Corp, The Mexican State and Compesino Dispossesion at The Penesquito Goldmine. Journal of Latin American Geography, Vol 10 No 2 pp 153-176.

Haryadi et al, 2018. Charismatic Leadership of Kiai in Developing an organizational Culture of Islamic Boarding School. The Journal of Educational Development, 6 (1) pp 44-53.

Holden dan Jacobson, 2008. Civil Society Opposition to Nonferrous Metals Mining in Guatemala. Voluntas : International of Voluntary and Nonprofit Organization, Vol 19 No 4 pp 325-350.

Puryanto, S, \& Susanto Didi. 2019. Konflik dan Gerakan Sosial di Rembang. Ombak

Puryanto, S. \& Suyahmo. 2019. Urban Social Movement in Indonesia. International Journal of Sciences and Research. Vol. 75 | No. 1/1 | Jan 2019. DOI: 10.21506/j.ponte.2019.1.10

Puryanto, S. 2018. Factors Mining Conflict; Local Perception (Cement Mining Conflict in Rembang Central Java Indonesia). International Journal of Science and Research (IJSR) 7 (11), 1356-1359.

Puryanto, S. Liesnoor D. S. Suyahmo. Jazuli M. 2018. Factors Cement Mining Conflit in Rembang Central Java, then Emerged Social Movement. Proceeding 7th Global Conference on Business and Social Science in Srilanka 
Sethi,at all, 2011. Freeport-Mc. Morran Copper \& Gold, Inc; An Innovative Voluntry Code of Conduct to Protect Human Rights, Create employment Opportunities and Economic Development of the Indigenous People. Journal of Business Ethics, Vol 103 No 1 pp 130

Suharko, 2013. Karst: Di Tambang atau di Lestarikan, Konflik Sosial Rencana Pembangunan Semen di Pati Jawa Tengah. Jurnal Ilmu Sosial Politik. Vol 17, no 2, (101-206).

Suharko, 2016. Masyarakat Adat versus Korporasi: Konflik Sosial Rencana Pembangunan Pabrik Semen di Kabupaten Pati Jawa Tengah Periode 2013-2016. Jurnal Ilmu Sosial Politik. Volume 20, Nomor 2, November 2016 (97-116)

Sukamto, 1999. Kepemimpinan Kyai dalam Pesantren. Jakarta: LP3ES 10. Ziemek, Mafred. 2007. Pesantren dalam Perubahan Sosial. Jakarta: P3M. 